\title{
Analisis Perbandingan Penentuan Hiposentrum Menggunakan Metode Grid Search, Geiger, dan Random Search: Studi Kasus pada Letusan Gunung Sinabung 2017
}

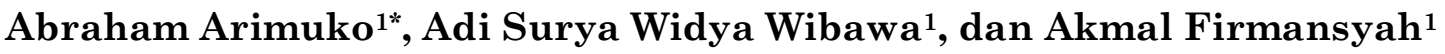 \\ 1Program Studi Geofisika, Sekolah Tinggi Meteorologi Klimatologi dan Geofisika, \\ Tangerang Selatan, Indonesia \\ *e-mail korespondensi: abrahamarimuko98@gmail.com \\ (masuk: 13-12-2019; revisi: 23-12-2019; diterima:31-12-2019)
}

\begin{abstract}
Abstrak: Penentuan lokasi hiposentrum gempa Bumi penting untuk dilakukan dengan cepat dan tepat. Hal tersebut bertujuan untuk mengetahui penyebab terjadinya gempa Bumi tersebut. Penelitian ini menggunakan input parameter hiposentrum awal, serta waktu penjalaran gelombang P. Data ini diperoleh dari BMKG Earthquakes Repository. Kejadian gempa Bumi yang digunakan adalah kejadian gempa Bumi pada 9 Februari 2017 dengan magnitudo gempa Bumi (MLv) 4,6 dan 4,2 pada kedalaman $10 \mathrm{~km}$. Posisi stasiun pencatat gempa juga digunakan dalam proses perhitungan. Data tersebut diinversi untuk mendapatkan posisi hiposentrum baru sebagai hasil dari perhitungannya. Selain itu, hasil dari perhitungan ini adalah lama pemrosesan yang akan dianalisis dalam penelitian ini. Hasil yang didapatkan dalam penelitian ini yaitu metode grid search membutuhkan waktu yang lebih lama dalam pemrosesan data dibandingkan metode Geiger karena iterasi Geiger cepat mendapatkan hasil optimum.
\end{abstract}

Kata kunci: hiposentrum, grid search, Geiger, random search

\section{Pendahuluan}

Indonesia adalah kawasan dengan gunung api muda dan berada di lempengan tektonik yang aktif bergerak. Akibat dari kondisi geologis seperti itu, Indonesia sering terjadi gempa Bumi, baik gempa vulkanik maupun gempa tektonik. Kekuatan gempa bisa diketahui setelah gempa terjadi dengan mempertimbangkan beberapa parameter. Salah satu parameter penting gempa Bumi adalah hiposentrum. Hiposentrum merupakan titik di dalam Bumi di mana sebuah gempa Bumi mulai terjadi (USGS).

Posisi sumber gempa Bumi yang presisi akan mempermudah untuk mengetahui mekanisme sumber gempa Bumi tersebut dan kekuatan gempa Bumi. Beberapa metode dikembangkan untuk menentukan hiposentrum secara akurat, diantaranya metode Grid Search (Sambridge, 1999), Geiger (Geiger, 1910,
1912), dan Random Search (Grandis, 2009). Penentuan hiposentrum dengan ketiga metode tersebut merupakan metode absolut karena tidak dipengaruhi oleh event yang lain.

Penentuan hiposentrum dengan ketiga metode itu menggunakan data observasi yang diinversi dengan data kalkulasi menggunakan parameter model tertentu. Pada metode Grid Search, dilakukan proses perhitungan setiap titik sampelnya yang terbentuk berdasarkan grid (Grandis, 2009). Lama proses inversi dipengaruhi oleh parameter input dan ruang wilayah yang diteliti. Metode Geiger menggunakan model awal hiposentrum terbaik sehingga didapatkan solusi terbaik (Sambridge dan Gallagher, 1993). Random Search digunakan untuk mengatasi proses perhitungan yang lama dari metode Grid Search. Prinsip perhitungannya adalah dengan mengkalikan parameter model 
dengan bilang acak yang probabilitasnya sama pada setiap datum dengan interval antara 0 sampai 1 (Grandis, 2009).

Penelitian ini menggunakan kejadian gempa Bumi di Gunung Sinabung yang tergolong Volcano-Tectonic earthquake (gempa Bumi V-T). Wilayah Gunung Sinabung dipilih karena terdapat sebaran stasiun seismograf yang melingkupi Gunung Sinabung. Penentuan waktu tiba gelombang yang tepat dan jaringan stasiun seismograf yang banyak di sekitar sumber gempa maka ketelitian posisi hiposentrum memiliki ketelitian sampai ratusan meter (Bourman, 2002). Selain itu, sumber gempa Bumi yang sudah pasti diakibatkan oleh aktivitas vulkanik Gunung Sinabung mempermudah untuk memvalidasi hasil penentuan hiposentrum.

Metode penentuan hiposentrum telah berkembang untuk mendapatkan hasil dengan cepat. Namun pada berbagai kasus, kecepatan pemrosesan data sering berbanding terbalik dengan akurasi dari hasil yang diperoleh. Tujuan analisis penentuan hiposentrum yang dilakukan dalam artikel ini adalah membandingkan metode yang paling optimal di antara ketiga metode tersebut dengan mengharapkan hasil hiposentrum terbaik.

\section{Metode Penelitian}

Ada beberapa seismograf Badan Meteorologi Klimatologi dan Geofisika (BMKG) yang terpasang di wilayah sekitar Gunung Sinabung. Seismograf Badan Meteorologi Klimatologi dan Geofisika (BMKG) di sekitar Gunung Sinabung ditunjukkan Tabel 1.

Tabel 1. Koordinat geografi dan elevasi letak stasiun (sensor) berdasarkan data letak sensor BMKG.

\begin{tabular}{lccl}
\hline $\begin{array}{c}\text { Kode } \\
\text { Stasiun }\end{array}$ & Lat. & Long. & \multicolumn{1}{c}{$\begin{array}{c}\text { El. } \\
(\mathbf{m})\end{array}$} \\
\hline TSI & $3,501{ }^{\circ} \mathrm{LU}$ & $98,565^{\circ} \mathrm{BT}$ & 81,8 \\
KCSI & $3,522{ }^{\circ} \mathrm{LU}$ & $97,772{ }^{\circ} \mathrm{BT}$ & 198 \\
PSI & $2,6955^{\circ} \mathrm{LU}$ & $98,924^{\circ} \mathrm{BT}$ & 1076,9 \\
LASI & $4,457{ }^{\circ} \mathrm{LU}$ & $97,970{ }^{\circ} \mathrm{BT}$ & 13 \\
TRSI & $2,026^{\circ} \mathrm{LU}$ & $98,959{ }^{\circ} \mathrm{BT}$ & 975,94 \\
\hline
\end{tabular}

Lat. : Latitude

Long. : Longitude

El. : Elevasi
Gempa Bumi yang tercatat dan telah dipilih waktu tiba gelombang primer (P) dan gelombang sekunder (S) disimpan di Earthquakes Repository BMKG dengan alamat 172.19.3.54/repository.php. Penelitian ini hanya menggunakan 2 data gempa Bumi yang terjadi pada 9 Februari 2017. Hiposentrum gempa Bumi pertama pada koordinat $3,28^{\circ} \mathrm{LU}$ dan $98,5^{\circ} \mathrm{BT}$ dengan kedalaman $10 \mathrm{~km}$. Sedangkan hiposentrum gempa Bumi kedua pada koordinat $3,34^{\circ} \mathrm{LU}$ dan $98.56^{\circ} \mathrm{BT}$ pada kedalaman $10 \mathrm{~km}$. Pada penelitian ini hanya digunakan waktu tiba gelombang $\mathrm{P}$ untuk menentukan posisi hiposentrum. Hal tersebut karena waktu tiba gelombang $\mathrm{P}$ lebih mudah ditentukan dibandingkan gelombang S. Stasiun (sensor) yang merekam waktu tiba gelombang $\mathrm{P}$ tersebut antara lain TSI, KCSI, PSI, LASI, dan TRSI. Pemilihan stasiun lokal dimaksudkan untuk menghindari perbedaan zona pembagian wilayah UTM. Penelitian ini melakukan konversi koordinat dari derajat ke meter. Hal tersebut bertujuan untuk merepresentasikan wilayah yang diteliti dalam bentuk bangun ruang tidak lengkung. Hasil yang didapatkan akan menunjukkan kemampuan algoritma yang digunakan.

Metode Grid Search dalam perhitungannya membutuhkan waktu yang bergantung pada parameter awal pada proses iterasi. Metode Grid Search merupakan pengembangan dari metode neighborhood yang dikembangkan oleh Sambridge (1999). Setiap grid yang selesai dihitung akan ditinjau nilai kesalahannya. Jika nilai kesalahan baru lebih kecil dari sebelumnya maka nilai baru tersebut menjadi nilai batasnya. Perhitungan ini akan tetap berlangsung sampai semua grid berhasil dihitung dan akan didapatkan nilai RMS (root mean square) terkecilnya sebagai solusi terbaik (Rodi dan Toksoz, 2000). Beberapa software yang menggunakan metode ini adalah HYPO71, HYPOELLIPSE, dan HYPOINVERSE (Bourmann, 2002). Jika $\tau$ merupakan selisih fungsi parameter awal $\boldsymbol{x}$ dengan solusi dari maximum likelihood $\boldsymbol{x}_{m l}$. di 
mana $\boldsymbol{x}=(x, y, z)$, maka fungsi tersebut dapat dituliskan (Rodi dan Toksoz, 2000):

$$
\tau(\boldsymbol{d}, x, y, z)=\min _{x, y, z} \widetilde{\Lambda}(\boldsymbol{x} ; \boldsymbol{d})-\widetilde{\Lambda}\left(\boldsymbol{x}_{m l} ; \boldsymbol{d}\right)
$$

Metode Geiger dikembangkan pertama kali oleh Geiger (1910) untuk menentukan posisi hiposentrum dengan mempertimbangkan parameter model awal (Bourmann, 2002). Salah satu software perhitungan hiposentrum menggunakan algoritma ini adalah GAD (Geiger's method with Adaptive Damping) (Nishi, 2005). Dasar perhitungan menggunakan metode Geiger adalah mencari residual terkecil (r) yang dipengaruhi oleh turunan parsial waktu terhadap posisi disetiap sumbu koordinat Cartesian $(x, y, z)$ serta selisih dari waktu tempuh pengamatan $\left(t_{o b s}\right)$ dengan waktu tempuh perhitungan ( $t_{h i t}$ ) yang dinotasikan $(\Delta t)$. Persamaan tersebut dapat ditunjukkan sebagai berikut:

$$
r_{i}=\frac{\partial T}{\partial x_{i}} \Delta x+\frac{\partial T}{\partial y_{i}} \Delta y+\frac{\partial T}{\partial z_{i}} \Delta z+\Delta t
$$

Solusi Matrik invers matrik $r$

Maka

$$
r=G \cdot X
$$

$$
X=\left(G^{T} * G\right)^{-1} G^{T} r
$$

$$
\text { Keterangan } \begin{aligned}
r & =\text { matrik data } \\
\mathrm{G} & =\text { matrik Karnel } \\
X & =\text { matrik model }
\end{aligned}
$$

Metode Random Sampling memiliki dasar pemikiran dari metode pencarian sistematik global (Grid Search) yang fungsi objektifnya dapat diperkirakan berdasarkan harga fungsi objektif pada sampel model yang dipilih acak (random) pada ruang model (Grandis, 2009). Akibatnya jumlah sampel model yang digunakan lebih sedikit dibandingkan dengan metode Grid Search sehingga proses perhitungan lebih efisien. Proses interpolasi perlu dilakukan untuk memperoleh bentuk fungsi objektif yang lebih menyeluruh. Metode ini disebut juga metode Monte-Carlo karena analogi proses penentuan bilangan pengali bersifat acak (bilangan random) (Grandis, 2009).
Algoritma metode Monte-Carlo mirip dengan persamaan 1 , sebagai berikut (Rodi dan Toksoz, 2000):

$$
\tau\left(\boldsymbol{d}^{m c}, x, y, z\right)=\widetilde{\Lambda}\left(\boldsymbol{x} ; \boldsymbol{d}^{m c}\right)-\widetilde{\Lambda}\left(\boldsymbol{x}_{m l}^{m c} ; \boldsymbol{d}^{m c}\right)
$$

$\tau$ adalah selisih fungsi parameter awal $\boldsymbol{x}$ dengan solusi dari maximum likelihood metode Monte-Carlo $\boldsymbol{x}_{m l}^{m c}$.

Maka perpandingan jumlah data dari metode pencarian sistematik global dengan sistematik acak dapat dituliskan:

$$
\tau(\boldsymbol{d}, x, y, z)>\tau\left(\boldsymbol{d}^{m c}, x, y, z\right)
$$

Salah satu parameter yang menunjukan solusi dari minimum global adalah nilai Root Mean Square (RMS) terkecil yang didapatkan. RMS tidak mendapatkan solusi terbaiknya jika parameter awal yang digunakan tidak tepat sehingga terjebak pada nilai minimum lokal (Ratchkovsky, 1998). Salah satu cara untuk menghindari nilai minimum lokal adalah memanfaatkan semaksimal mungkin informasi "a priori" yang tersedia untuk menentukan model parameter awal (Grandis, 2009).

Perhitungan yang digunakan untuk menguji ketiga metode tersebut memakai bahasa pemrograman Matlab. Perhitungan menggunakan input data posisi hiposentrum, model kecepatan, waktu perambatan gelombang, dan posisi stasiun seismograf yang merekam sinyal seismik. Model kecepatan yang digunakan merupakan model kecepatan lokal di sekitar wilayah Gunung Sinabung (Arimuko, dkk., 2018) seperti ditunjukkan pada Tabel 2.

Tabel 2. Model kecepatan 1-D Gelombang Seismik di wilayah Gunung Sinabung.

\begin{tabular}{ccc}
\hline Kedalaman $\mathbf{( k m )}$ & $\mathbf{v}_{\mathbf{p}} \mathbf{( \mathbf { k m } / \mathbf { s } )}$ & $\mathbf{v}_{\mathbf{s}} \mathbf{( \mathbf { k m } / \mathbf { s } )}$ \\
\hline 0,0 & 5.9200 & 2,9100 \\
20,00 & 6.0300 & 3,4600 \\
20,01 & 6.5900 & 3,4600 \\
35,00 & 6.6400 & 3,7500 \\
35,01 & 7.7100 & 4,4700 \\
71,00 & 8.0400 & 4,4800 \\
120,00 & 8.0500 & 4,5000 \\
120,01 & 8.0500 & 4,5000 \\
\hline
\end{tabular}


Model kecepatan yang digunakan dalam perhitungan adalah model kecepatan gelombang $\mathrm{P} \quad\left(\mathrm{v}_{\mathrm{p}}\right)$ pada kedalaman 0-20 km. Hal tersebut dilakukan karena kedalaman gempa Bumi dari kedua kejadian adalah $10 \mathrm{~km}$ di bawah permukaan Bumi. Output dari pengolahan ini adalah posisi hiposentrum baru.

\section{Hasil dan Pembahasan}

Ketiga metode tersebut menghasilkan nilai hiposentrum baru dengan lama waktu pemrosesan berbedabeda. Penentuan parameter awal pada pembuatan grid sangat mempengaruhi proses perhitungan. Parameter yang digunakan pada metode Grid Search untuk menentukan dimensi wilayah yang dihitung $(x, y, z)$ adalah $131500 \times 268900 \mathrm{x}$
9000 dengan jarak antar grid 1000 (dalam meter) bertujuan untuk mempercepat proses perhitungan. Ketika jarak antar grid 100 meter maka kesalahan error yang mungkin terjadi sebesar \pm 50 meter namun waktu pemrosesan lebih dari 1 jam berdasarkan uji pengolahan yang telah dilakukan. Pada metode Geiger diperlukan parameter awal yang dianggap mendekati kondisi sebenarnya. Untuk mendekati kondisi sebenarnya maka parameter awal yang digunakan dalam metode ini menggunakan solusi perhitungan menggunakan metode Grid Search. Sedangkan pada metode Random Search digunakan 10000 dari 318243 data pada Grid Search. Perbedaan jumlah data tersebut mengakibatkan perbedaan yang sangat signifikan pada durasi pemrosesan.

Tabel 3. Perbandingan Hiposentrum Sebelum dan Sesudah Pemrosesan Menggunakan Metode Grid Search, Geiger, dan Random Search.

\begin{tabular}{|c|c|c|c|c|c|c|}
\hline $\begin{array}{l}\text { Gempa Bumi } \\
\text { ke- }\end{array}$ & & 1 & & & 2 & \\
\hline $\begin{array}{l}\text { Koordinat } \\
\text { UTM dan } \\
\text { Kedalaman }\end{array}$ & $\begin{array}{l}\text { Easting } \\
\text { (meter) }\end{array}$ & $\begin{array}{l}\text { Northing } \\
\text { (meter) }\end{array}$ & $\begin{array}{l}\text { Kedalaman } \\
\text { (meter) }\end{array}$ & $\begin{array}{l}\text { Easting } \\
\text { (meter) }\end{array}$ & $\begin{array}{l}\text { Northing } \\
\text { (meter) }\end{array}$ & $\begin{array}{l}\text { Kedalaman } \\
\text { (meter) }\end{array}$ \\
\hline $\begin{array}{l}\text { Hiposentrum } \\
\text { Awal }\end{array}$ & 444452,35 & 362556,39 & 10000 & 451121,15 & 369185,48 & 10000 \\
\hline $\begin{array}{l}\text { Hiposentrum } \\
\text { Metode Grid } \\
\text { Search }\end{array}$ & 445000 & 362900 & 9900 & 451000 & 369900 & 9900 \\
\hline $\begin{array}{l}\text { Hiposentrum } \\
\text { Metode } \\
\text { Geiger }\end{array}$ & 446820 & 368120 & 25640 & 445950 & 365780 & 14530 \\
\hline $\begin{array}{l}\text { Hiposentrum } \\
\text { Metode } \\
\text { Random } \\
\text { Search }\end{array}$ & 441824 & 363339 & 9630 & 443581 & 364615 & 9907 \\
\hline
\end{tabular}

*UTM: Universal Transverse Mercator

*Easting: komponen hasil proses transformasi perubahan dari garis bujur dalam satuan meter

*Northing: komponen hasil proses transformasi perubahan dari garis lintang dalam satuan meter

Berdasarkan Tabel 3, hiposentrum baru yang didapatkan dari ketiga metode memiliki nilai yang mendekati dengan hiposentrum awal. Durasi pemrosesan data pada metode Grid Search membutuhkan waktu kurang dari 30 detik dengan nilai RMS error optimum kurang dari 1 seperti ditunjukkan Gambar 1. Berdasarkan Gambar 1, diketahui bahwa pada iterasi ke-137 dan 145 nilai RMS error sudah mencapai hasil optimum dengan nilai kurang dari 1.

Metode Geiger memiliki kedalaman yang berbeda jauh dengan hiposentrum awal dan model parameter awal yang diambil dari hasil pemrosesan metode Grid Search. Metode Geiger membutuhkan model awal karena metode ini merupakan metode iteratif yang dipengaruhi oleh model awal. Hal ini berbeda dengan metode 
Grid Search dan Random Search yang memperhitungkan model kecepatan awal dan waktu penjalaran sebagai data perhitungannya. Pemrosesan ini dilakukan 10 iterasi untuk mengetahui pada iterasi berapa nilai tersebut akan optimum. Meskipun terlihat jauh perbedaan posisi hiposentrum, nilai RMS error dari pemrosesan ini dibawah 0.55 seperti terlihat pada Gambar 2. Berdasarkan Gambar 2, diketahui bahwa pada iterasi ketiga nilai RMS error sudah mencapai hasil optimum.

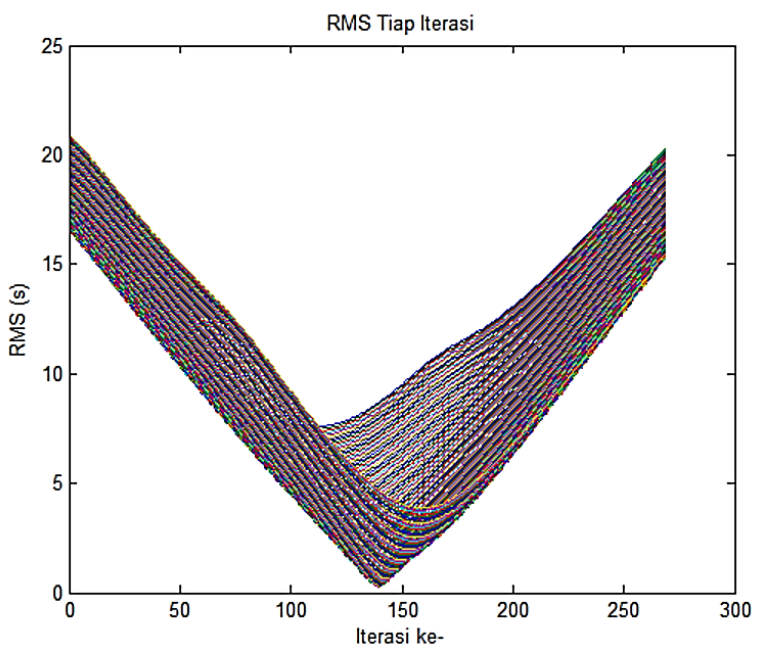

(a)
Metode Random Search memiliki hasil yang berbeda-beda pada setiap hasil pemrosesannya. Hal tersebut dipengaruhi oleh bilangan random yang muncul sebagai faktor pengali pada fungsi objektif. Jika bilangan random yang muncul memiliki nilai besar pada skala 0 sampai 1 maka hasil pemrosesan akan mendekati nilai hiposentrum awal. Algoritma metode Random Search juga tidak diketahui pada iterasi keberapa mencapai error optimum sehingga tidak dapat dilakukan pembatasan jumlah iterasi. Plot RMS error seperti terlihat pada Gambar 3.

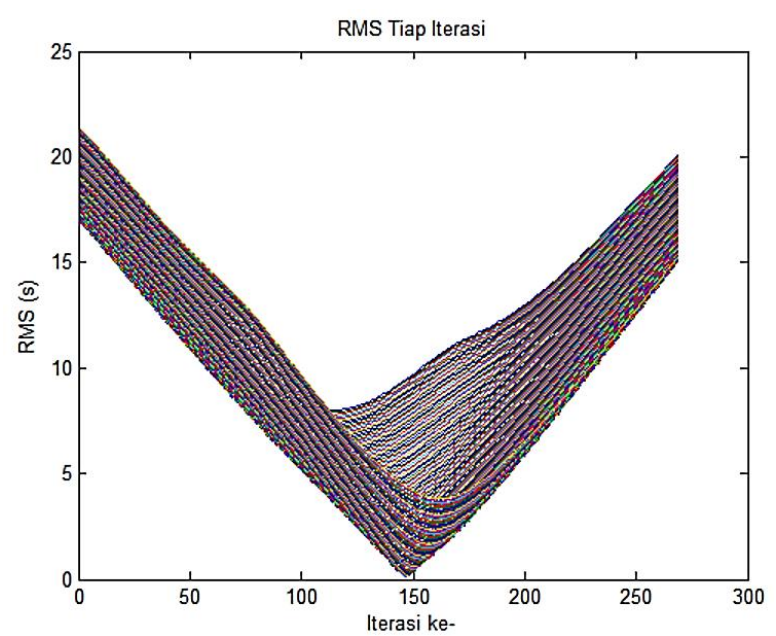

(b)

Gambar 1. RMS error untuk Metode Grid Search Gempa Bumi G. Sinabung 9 Februari 2017. (a) Nilai RMS error kejadian gempa pertama dan (b) Nilai RMS error kejadian gempa kedua.

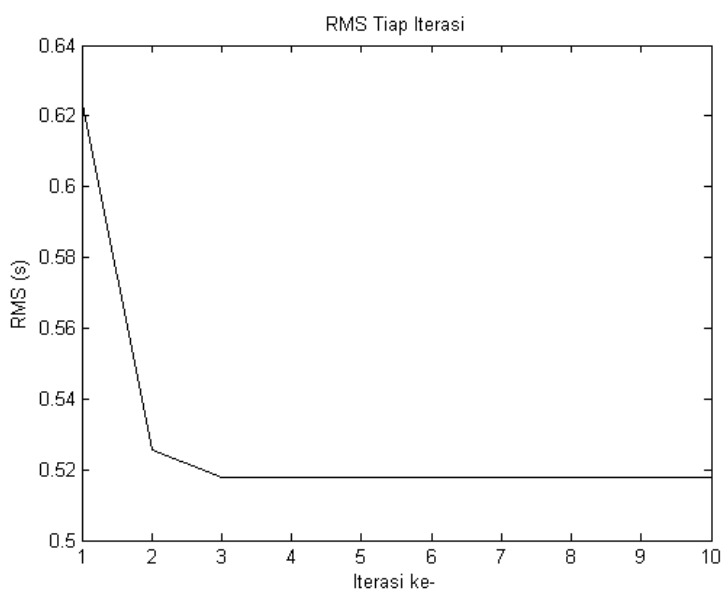

(a)

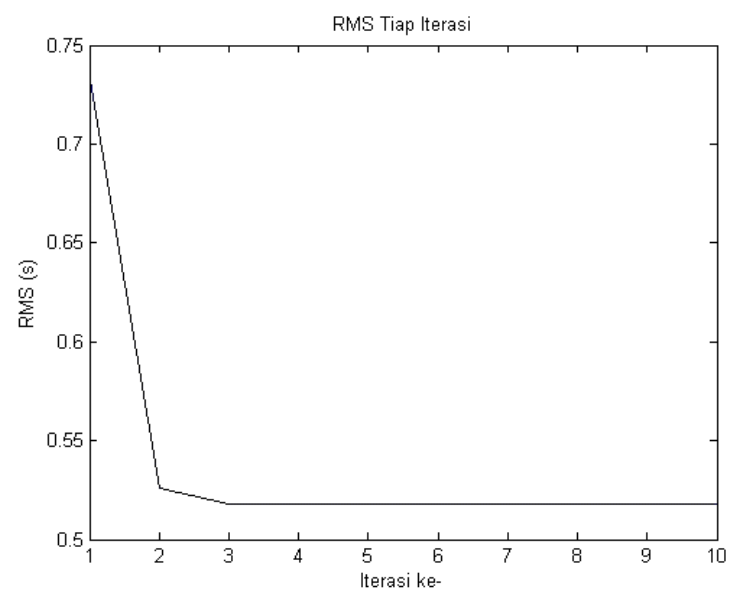

(b)

Gambar 2. RMS error untuk Metode Geiger Gempa Bumi G. Sinabung 9 Februari 2017.

(a) Nilai RMS error kejadian gempa pertama dan (b) Nilai RMS error kejadian gempa kedua. 


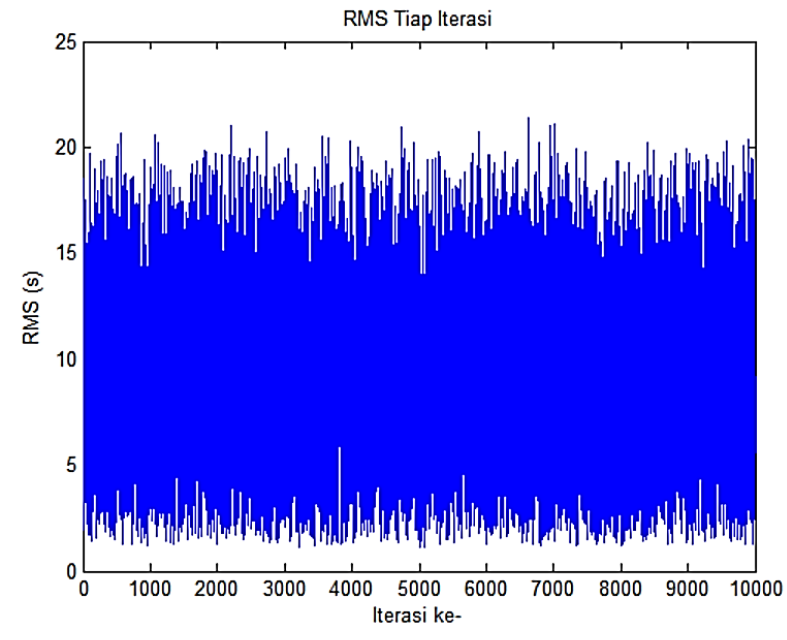

(a)

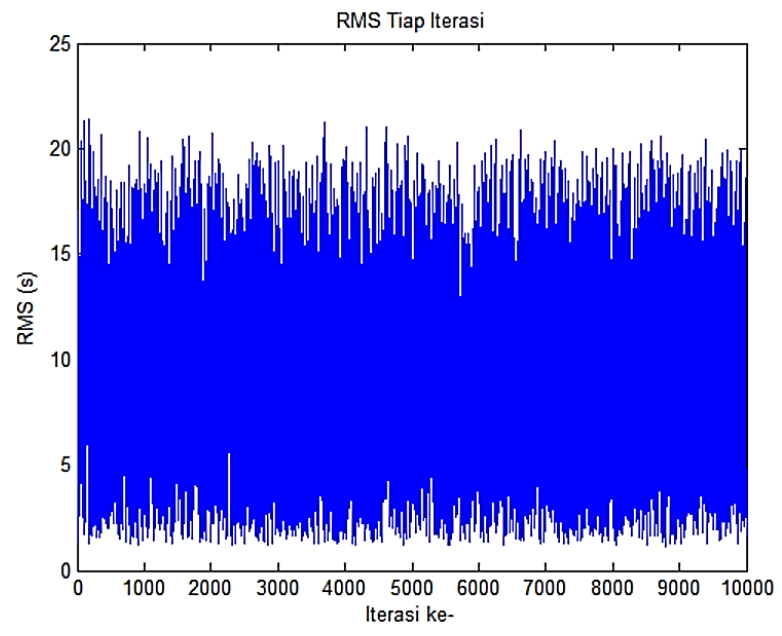

(b)

Gambar 3. RMS error untuk Metode Random Search Gempa Bumi G. Sinabung 9 Februari 2017. (a) Nilai RMS error kejadian gempa pertama dan (b) Nilai RMS error kejadian gempa kedua.

Berdasarkan analisis RMS error, metode Grid Search membutuhkan iterasi yang lebih banyak daripada metode Geiger. Hal ini berarti metode Grid Search membutuhkan waktu lebih lama dalam pemrosesan. Sementara itu, pemrosesan data menggunakan metode Random Search lebih cepat dari pada Grid Search namun hasilnya kurang konsisten. Hal ini karena metode Random Search setelah dilakukan beberapa ribu kali tidak diketahui pada iterasi keberapa mencapai error optimum sehingga pembatasan jumlah iterasi tidak dapat dilakukan. Dengan demikian, metode Random Search secara umum membutuhkan waktu pemerolehan posisi hiposentrum secara konsisten yang lebih lama daripada metode Grid Search dan Geiger. Hal ini berbeda dengan Grandis (2009).

\section{Penutup}

Penelitian ini telah melakukan proses perhitungan dan membandingkan tiga metode yaitu metode Grid Search, metode Geiger, dan metode Random Search untuk menentukan letak hiposentrum pada kasus gempa Bumi Gunung Sinabung tahun 2017. Berdasarkan perbandingan ketiga metode tersebut dan hiposentrum awal, disarankan dalam algoritma penentuan hiposentrum pada program analisis gempa Bumi adalah metode Grid
Search. Hal ini karena metode Grid Search lebih mendekati hasil hiposentrum awal.

Penelitian ini menunjukkan metode Random Search membutuhkan waktu pemrosesan yang lebih lama daripada metode Grid Search dan Geiger karena hasil metode Random Search kurang konsisten walau telah dilakukan lebih dari 2000 iterasi RMS. Sementara itu, penggunaan metode Grid Search membutuhkan waktu yang lebih lama daripada metode Geiger walau metode Grid Search lebih mendekati hasil hiposentrum awal. Masalah durasi pemrosesan metode Grid Search dapat diatasi dengan memperbesar jarak antar grid. Penelitian lebih lanjut perlu dilakukan untuk mengetahui jarak antar grid agar mendapatkan hasil dan waktu pemrosesan yang optimum.

\section{Referensi}

Arimuko, A., dkk. (2019). Model Kecepatan 1-D Gelombang $\mathrm{P}$ dan Gelombang $\mathrm{S}$ dari Data Hasil Relokasi Hiposenter di Wilayah Gunung Sinabung. Jurnal Meteorologi Klimatologi dan Geofisika. 5 (3): 72-79.

Bormann, P. (2002). Global 1-D Earth models. GeoForschungsZentrum Potsdam, Telegrafenberg, D-14473 Potsdam, Germany. 
Grandis, H. (2009). Pengantar Pemodelan Inversi. Himpunan Ahli Geofisika Indonesia. Jakarta 12540, Indonesia.

Geiger, L. (1910). Herdbestimmung bei Erdbeben aus den Ankunftszeiten. Nachrichten von der Königlichen Gesellschaft der Wissenschaften zu Göttingen, MathematischPhysikalische Klasse, 331-349. (1912 translated to English by F.W.L. Peebles and A.H.Corey: Probability method for the determination of earthquake epicenters from the arrival time only. Bulletin St. Louis University 8, 60-71).

Kanamori, H. (1972). Mechanism of Tsunami Earthquakes. Physics of the Earth Planetary Interiors. 11, pp. 312-332.

Nishi, K., 2005. Hypocenter Calculation Software GAD (Geiger's method with Adaptive Damping). Silver Expert JICA Indonesia version 1.

Rodi, W. dan Toksoz, M. N., 2000. GridSearch Techniques for Seismic Event Location. Conference paper. Massachusetts Institute of Technology. Cambridge Earth Resources Lab.

Sambridge, M. dan Gallagher, K., 1993. Earthquake Hypocenter Location Using Genetic Algorithms. Bulletin Seismological Society of America. 83 (5): 1467-1491. 